Szekspirowska struktura posłużyła Rohmerowi jako szkielet konstrukcyjny, na którym mógł zbudować swoją opowieść o zwykłym życiu i zaskakujących wydarzeniach, jakie się na nie składają. Happy end Rohmera jest bowiem czymś nadzwyczajnym tylko pozornie. W rzeczywistości - tak jak patrzy na nią Félicie dochodzi do niego w sposób jak najbardziej naturalny, a przypadkowe spotkanie ukochanego $\mathrm{w}$ autobusie (choć równie niezrozumiałe jak pomylenie własnego adresu) to nic innego jak spełnienie oczekiwań głównej bohaterki,

[11] Nie sposób całkowicie wykluczyć - zwłaszcza biorąc pod uwagę fakt, że Félicie doznaje swego rodzaju iluminacji w katedrze - możliwości odczytania Rohmerowskiego happy endu jako zrządzenia Opatrzności, choć taka interpretacja rzeczywistości jest obca bohaterce, która deklaruje się jako osoba areligijna. która od dawna powtarzała, że odnalezienie Charles’a jest możliwe[11].

Wypełniające cały film oczekiwanie na ten moment pozwoliło Rohmerowi także na śledzenie zmian zachodzących w psychice Félicie, na ukazanie wewnętrznej drogi, jaką musiała przebyć, by powrócić do zagubionego stanu „bycia sobą". Także i w tej, wewnętrznej warstwie niezwykle istotne okazało się odwołanie do Szekspira. Rohmer ukazał psychologiczną odyseję Félicie, czyniąc z niej odpowiednik Szekspirowskiej Perdity, nieznającej swojej prawdziwej tożsamości. Tym samym jego Opowieść zimowa stała się narracją o tym, co determinuje los każdego człowieka, co niedocieczone w ludzkich wyborach, o próbie zrozumienia samego siebie. Wreszcie też - i do tego komedia Szekspira okazała się niezbędna - o tym, że nie zawsze to, co wydaje się stracone bezpowrotnie, musi być niemożliwe do odzyskania.

\title{
Autorstwo utworu audiowizualnego - substancja i struktura
}

\section{MAREK HENDRYKOWSKI}

Artykuł ten zawiera trzy hipotezy badawcze - wszystkie z natury swej dyskusyjne, jak dyskusyjna od bardzo dawna aż do dziś jest kwestia autorstwa filmu i utworu audiowizualnego. Wspomniane trzy hipotezy przedstawiają się następująco:

Hipoteza pierwsza: film i utwór audiowizualny jest dziełem autorskim, a autorstwo utworu audiowizualnego ma charakter tyleż przynależny poszczególnemu twórcy, co zespołowy $\mathrm{i}$ interpersonalny.

Hipoteza druga: autorstwo filmu i utworu audiowizualnego jest funkcją zapisaną i utrwaloną w jego określonym kształcie i strukturze semantycznej.

Hipoteza trzecia: autorstwo dzieła filmowego i utworu audiowizualnego ma charakter zmienny historycznie, będąc zjawiskiem zależnym od stopnia rozwoju kultury artystycznej, kultury komunikowania, kultury produkcji i wytwarzania ruchomych obrazów oraz, last but not least, kultury i jurysdykcji prawnej panującej w danym miejscu i czasie.

\section{Morfologia autorstwa}

Autorstwa komunikatu złożonego $\mathrm{z}$ ruchomych obrazów nie należy traktować jako cechy dodatkowej i występujacej fakultatywnie. W każdej ze swoich indywidualnych form, postaci i odmian jest ono integralną funkcją danego dzieła filmowego czy - szerzej - utworu audiowizualnego. Funkcją, która - za pośrednictwem struktury semantycznej tekstu - kreuje i wyraża jego indywidualnego i zespołowego 
twórcę. W zależności od stylu i stopnia oryginalności danego utworu jako tekstu kultury autorstwo bywa natychmiast rozpoznawalne bądź niemal niezauważalne. Wyrazistość funkcji autorstwa zapisana w utworze, wraz z jej repartycją dotyczącą poszczególnych udziałów twórczych, przekłada się na ocenę (nie tylko artystyczną) konkretnego dzieła.

Kategoria pojęciowa „utworu audiowizualnego" jest z natury czym innym niż kategoria „dzieła kinematograficznego” (w tym dzieła filmowego). Dzieło kinematograficzne (w tym filmowe) jako specyficzna postać utworu audiowizualnego pozostaje $\mathrm{z}$ istoty swojej dziełem autorskim, podczas gdy przekaz audiowizualny niekoniecznie i nie zawsze. Drugie z tych pojęć pozostaje zatem nie tylko węższe w zakresie znaczeniowym, ale także - poprzez nieistotny i nieobecny w nim aspekt sztuki - jakościowo odmienne od pierwszego.

Niezależnie od powyższego, uzasadnionego aksjologicznie i kulturowo rozróżnienia, każda bez wyjątku postać autorstwa utworu filmowego i audiowizualnego pozostaje w ścisłej zależności i wielofunkcyjnym powiązaniu $\mathrm{z}$ jego morfologią i jednocześnie aksjologią. Kryteria aksjologiczne - powiązane $\mathrm{z}$ konwencją kulturową, która je tak, a nie inaczej określa - odgrywają pierwszorzędnie ważną rolę w procesie definiowania autorstwa. Generalna zasada pozostaje jednak prosta: im lepsze i oryginalniejsze (resp. wartościowsze) dzieło, tym bardziej zauważalne jest jego autorstwo.

Dochodzimy w tym momencie do kwestii o zasadniczym znaczeniu dla zagadnienia autorstwa i procedur jego atrybucji - wkładu autorskiego pojedynczego współtwórcy dzieła. Podstawowy dylemat z nim związany polega na tym, że podejście sumaryczne w tym przypadku nie tylko nie wystarcza, ale okazuje się mylące, prowadzi do zasadniczych nieporozumień. Piękne zdjęcia lub świetna muzyka, podobnie jak znakomicie napisany scenariusz i brawurowa reżyseria, wzięte $z$ osobna jako wkład indywidualny rozłączny od innych wkładów, nie przesądzają o autorskim wyposażeniu i wartości utworu. W przypadku autor- stwa liczy się komunikat jako całość. Dlaczego właśnie on?

Nie istnieje autorstwo dzieła kinematograficznego oraz utworu audiowizualnego poza tekstem (przekazem, komunikatem), jaki utwór ten stanowi. Autorstwo znaczy, czyli wielorako współtworzy strukturę semantyczną przekazu. Każdy $\mathrm{z}$ autorów i współautorów utworu audiowizualnego ma w nim swój udział. Precyzyjne określenie rozłącznego i łącznego współudziału pojedynczego twórcy nie jest sprawą błahą ani łatwą. Powód trudności, a także niemożności, jakie pociąga za sobą każda próba repartycji, tkwi w kwestii twórczej kooperacji, dzięki której dany utwór nie tylko powstał, ale - co ważniejsze - osiągnął określony kształt, stając się utworem autorskim.

\section{Nieco historii}

Autorstwo filmu ma swoją historię. Jako akt twórczy i funkcja społeczna jest ono elementem składowym kultury filmowej, kultury komunikowania i systemu kultury jako całości. Społeczny fenomen autorstwa odnosi się do procesu komunikowania. Wszędzie tam, gdzie w grę wchodzi triada: nadawca - utwór - odbiorca, mamy do czynienia $z$ autorstwem przekazu. Jak każdy aspekt kultury, ewoluuje ono nieustannie, podlegając procesowi historycznej zmienności. U swych początków ruchome obrazy nie były jeszcze czymś, co traktowano jako domenę twórczości i sztuki, ale już ewokowały kwestię praw do ich autorstwa.

$\mathrm{Z}$ naszej perspektywy mogłoby się wydawać, że autorstwo utworu audiowizualnego jest kwestią raz na zawsze ustaloną. Tymczasem nic podobnego. Poszczególne epoki dziejów kinematografii rozmaicie rozpoznawały i sytuowały pierwiastek autorstwa. Emancypacja kulturowa sztuki filmowej zaczęła się na przełomie XIX i XX wieku od adaptacji dzieł literackich i scenicznych. W tamtej, wczesnej fazie rozwoju kultury, twórczości i sztuki filmowej artystą i „autorem” najczęściej nie był jeszcze reżyser, lecz znany pisarz względnie dramaturg.

Eksponowaną rolę oraz autorski prestiż pisarza i dramaturga przejął po pewnym czasie 
scenarzysta. Zwłaszcza w dawnej kinematografii niemieckiej jego pozycja została tak bardzo eksponowana, iż w drugiej i trzeciej dekadzie $\mathrm{XX}$ wieku pojawiło się określenie „Autorenfilm”, z wyraźnym adresem scenariopisarskim. $\mathrm{Z}$ kolei funkcjonujące do dzisiaj, znamienne określenia „art director” i „art direction” sygnalizują bardzo wysoką w tamtej epoce pozycję malarzy-scenografów pracujących dla przemysłu filmowego jako „prawdziwi artyści”, w odróżnieniu od szeregu innych fachów filmowych (reżyser, operator i in.), powszechnie uważanych w początkach kinematografii za „nieartystyczne” i „techniczne”.

$\mathrm{Na}$ styku przemysłu kinematograficznego i sztuki filmowej już w epoce kina niemego niejednokrotnie dochodziło do ostrych konfliktów o autorstwo danego utworu. Odpowiedzią na owe ambicje i rozmaite indywidualne aspiracje zgłaszane przez poszczególnych twórców stała się praktyka panująca w przemyśle filmowym. W hollywoodzkiej „fabryce snów”, zorganizowanej na podobieństwo koncernu Forda, taśmowa produkcja filmów potrzebowała nie kapryśnych i nieprzewidywalnych „artystów”, lecz uzdolnionych specjalistów sprawnie wykonujących powierzone zadanie. Ich stopniowa emancypacja w roli „autora” nie została całkowicie powstrzymana. Dokonywała się jednak $\mathrm{z}$ wielkimi oporami.

W wytwórniach Wielkiej Piątki, zwanych Majors, i Małej Trójki, określanych mianem Minors, rządzili potężni liderzy (nieprzypadkiem nazywani „moguls” albo „tycoons”). Z nadania tychże procesem produkcji i przemysłowo zorganizowanym kręceniem filmów dyrygowali wszechwładni szefowie produkcji w rodzaju Irvinga Thalberga i Darryla F. Zanucka. Oprócz nich funkcjonowali także producenci niezależni (David O. Selznick, Walter Wanger, Roger Corman i in.). W studiach filmowych rządzili jednak wielcy potentaci: Samuel Goldwyn, Jesse L. Lasky, Louis B. Mayer, Harry Cohn. Sławni filmowcy, na przykład mistrzowie reżyserii, pracowali dla swoich bossów zatrudniani przez nich na kontraktach, ale tylko bardzo nieliczni potrafili sobie wywalczyć margines twórczej wolności i w miarę niezależną pozycję, na przykład jako director-producer (Fritz Lang, Howard Hawks, John Huston i niewielu innych).

W latach czterdziestych, a zwłaszcza pięćdziesiątych XX wieku dokonało się gruntowne zreorientowanie świadomości kwestii autorstwa dzieła filmowego. W najlepiej na świecie zorganizowanej kinematografii amerykańskiej, nie bez przyczyny uważanej w Stanach Zjednoczonych za jeden z przemysłów narodowych tego państwa, pozycję hegemona w kwestii autorstwa filmowego po dawnemu dzierżył producent jako ten, kto od początku do końca odpowiada za daną produkcję, angażując do jej urzeczywistnienia wszystkich innych twórców: scenarzystę, reżysera, operatora, scenografa, kompozytora, aktorów i in.

W Europie z kolei pojawiło się i wkrótce zdobyło wielkie uznanie zjawisko „cinéma des auteurs”, a wraz z nim niepomiernie wzrosła pozycja i zawodowy prestiż reżysera jako głównego autora dzieła. W polskiej kulturze filmowej i audiowizualnej zjawisko to wywarło zasadniczy wpływ na dominujące $\mathrm{u}$ nas wyobrażenie autora i autorstwa dzieła filmowego. Nie do końca jednak, w praktyce bowiem, mamy dzisiaj w Polsce do czynienia z konfliktem obu wspomnianych wyżej modeli: producenckiego (od pewnego czasu w ofensywie) i reżyserskiego (w defensywie).

Negatywne skutki presji modelu producenckiego w filmie i przekazach audiowizualnych trafnie opisał i przenikliwie zdiagnozował przed laty znawca prawa autorskiego Jan Błeszyński, pisząc:

Należy jednak pamiętać o tym, że twórca jest $\mathrm{w}$ relacji do producenta utworu audiowizualnego stroną słabszą. Producent, korzystając ze swojej przewagi ekonomicznej, jest w stanie narzucić twórcy niekorzystne warunki umowy. Jednocześnie, i to jest nie mniej ważny element motywacyjny omawianych zasad, z tworzeniem utworu związana jest niewiadoma co do jego walorów rozstrzygających o sukcesie, miarą którego okaże się skala jego przyszłej eksploatacji. Są, jak wiadomo, utwory audiowizualne, które okazują się ogromnym sukcesem artystycznym i kasowym. Są jednak i takie, 
które sukcesu nie odnoszą, co zresztą nie zawsze pozostaje $\mathrm{w}$ związku $\mathrm{z}$ ich małą artystyczną wartością. W tym kontekście zagwarantowanie wprost w ustawie określonym kategoriom twórców, których wkład ma zasadnicze znaczenie dla wartości utworu audiowizualnego, udziału w korzyściach płynących z eksploatacji utworu audiowizualnego jako całości, stanowi przejaw zarówno troski o zachowanie gospodarczej równowagi, jak i zabezpieczenie twórcom minimum korzyści, przy ograniczeniu ich ciężaru dla producenta[1].

Wariant producencki atrybucji autorstwa w wersji amerykańskiej czyni producenta wyłącznym autorem i jedynym posiadaczem wszelkich praw do utworu, nadając wszystkim jego współtwórcom (scenarzyście, adaptatorowi, reżyserowi, operatorowi, twórcy muzyki etc.) podrzędny status wykonawców/realizatorów działających na zlecenie producenta i uczestniczących w powstaniu danego utworu na zasadzie „hired hand”. Można tutaj mówić o dawno temu ukształtowanym, powszechnie panującym modelu relacji i zależności między producentem filmu a jego realizatorami w funkcji nie tyle pełnoprawnych autorów, co wynajętych wykonawców.

Uzus ten bywa zmieniany dość rzadko i jedynie w szczególnych przypadkach, w których kontrakt o dzieło zawierany $\mathrm{z}$ danym twórcą stanowi inaczej, udzielając mu umownej części praw należnych producentowi. Całkiem inaczej wygląda to w europejskiej kulturze filmowej, gdzie za głównego autora dzieła uważa się reżysera, uwzględniając i chroniąc jednocześnie autorskie prawa pewnej grupy innych jego twórców uważanych za współautorów utworu filmowego i audiowizualnego. Można tu zatem mówić o istnieniu dwu różnych tradycji rozumienia autorstwa filmu i utworu audiowizualnego.

\section{Koncepcje autorstwa}

Po tym koniecznym objaśnieniu historycznym łatwiej nam będzie zaprezentować trzy konkurencyjne modele twórczości i autorstwa utworu filmowego i audiowizualnego:

1. monoautorski,
2. addytywny,

3. interakcyjny.

Ad 1. W modelu monoautorskim (resp. jednopodomiotowym) całość autorstwa dzieła należy do jednego twórcy. Może nim być scenarzysta, reżyser, operator lub producent. Wszyscy inni twórcy, współtwórcy i realizatorzy są w tym modelu wykonawcami wynajętymi do zaprojektowania i realizacji powstającego utworu, jego ostateczny kształt zależy jednak od decyzji i woli jednego autora-decydenta niepodzielnie panującego nad całością na wszystkich etapach realizacji danego dzieła. Pozostali wnoszą swoją część pracy na zasadach zamówionego elementu, będącego cząstką konstrukcji, której wyłącznym i w pełni niezależnym autorem jest jeden określony podmiot (producent, wytwórnia, zespół twórczy, instytucja filmowa, państwowy zleceniodawca).

Ad 2. W modelu addytywnym (inaczej zwanym modelem sumarycznym) autorstwo utworu audiowizualnego nie przynależy do nikogo wyłącznie, lecz rozkłada się na szereg współautorskich udziałów. Podmiotami autorskimi są w świetle tej koncepcji autorstwa: producent, scenarzysta, adaptator, dialogista, reżyser, autor zdjęć, kompozytor muzyki, autorzy utworu słowno-muzycznego jako uprawnieni współtwórcy danego dzieła. Model addytywny pojmuje autorstwo jako indywidualny wkład twórczy wniesiony w dzieło jako całość. Poszczególnym uprzednio wymienionym podmiotom przysługuje wspólnie i z osobna status autora (współtwórcy danego utworu) w umownie przyjętym ułamku całości.

Oprócz niewątpliwych zalet, do których należy w pierwszym rzędzie przejrzystość indywidualnych udziałów, a wraz z nimi osobistych atrybucji i repartycji, addytywny model autorstwa ma jedną istotną wadę. Traktuje on mianowicie autorstwo w sposób statyczny: jako sumę poszczególnych udziałów (scenariusz +

[1] J. Błeszyński, Reemisja utworów objętych art. 70 ust. 2 ustawy o prawie autorskim i prawach pokrewnych, „Przegląd Ustawodawstwa Gospodarczego" 2005, nr 12, s. 2. 
reżyseria + zdjęcia + muzyka etc.), tracąc z pola widzenia fenomen samej twórczości (ergo autorstwa dzieła kinematograficznego). Nie wolno zapominać, iż film jako artefakt oraz utwór audiowizualny są $\mathrm{z}$ reguły dziełem zbiorowym (création collective). Aspekt ten, pomijany przez dwa poprzednie koncepcje twórczości operującej językiem ruchomych obrazów, bierze pod uwagę dopiero trzeci ze wskazanych modeli autorstwa - interakcyjny.

Ad 3. W modelu interakcyjnym autorstwo utworu filmowego i audiowizualnego jest funkcją rozłożoną międzyosobowo. W modelu tym dzieło filmowe i audiowizualne nie ma jednego autora. Z praktyki twórczej wiadomo, iż powstaje ono nie na zasadzie addycji poszczególnych wkładów jako suma udziałów, lecz w długotrwałym procesie wymiany i twórczej synergii dokonującej się pomiędzy twórcami dzieła. Model interakcyjny nie neguje znaczenia poszczególnych indywidualnych wkładów i udziałów, stawia natomiast w innym świetle fundamentalną dla naszych rozważań kwestię rozumienia procesu twórczego w filmie i utworze audiowizualnym.

Nie wolno tracić z pola widzenia faktu, że autorstwo utworów filmowych i audiowizualnych nie jest aktem izolowanym i jednokrotnym. Dzieje się ono na różnych etapach i w kolejnych stadiach ich powstawania. Rzecz w tym, iż dzieło filmowe i audiowizualne powstaje nie raz, lecz wielokrotnie. Dzieje się tak nie tylko w oparciu o zasadę następstwa (faza preprodukcji, produkcji i postprodukcji), lecz również - co szczególnie ważne, a pominięte $\mathrm{w}$ dwóch poprzednio omawianych modelach autorstwa - w interpersonalnej wymianie będącej źrodłem cennej inspiracji.

Interakcyjny model autorstwa różni się od dwóch poprzednich tym, że bazuje na koncepcji serii przemian struktury powstającego utworu: od projektu zapisanego w scenariuszu, do ostatecznie zrealizowanego efektu. Utwór audiowizualny (w tym dzieło filmowe) powstaje w rozłożonym na szereg etapów wielofazowym

[2] „Zdanie” 1987, nr 4, „Polityka” 1987, nr 22. procesie twórczym. Model ten oddaje faktyczną rzeczywistość wynikającą z praktyki twórczej, lecz jednocześnie komplikuje kwestię pojedynczego wkładu twórczego, ergo repartycji autorstwa. W świetle interakcyjnego modelu twórczości filmowej bywa ona nie tylko rozłączna, ale i łączna, i nie tylko jednoosobowa, lecz również międzyosobowa.

Dzieło filmowe nie jest zatem prostą sumą autorskich wkładów wnoszonych przez poszczególnych twórców. Podobnie ma się rzecz z kwestią udziałów. Potencjał twórczy ekipy pracującej nad danym filmem jest czymś nieporównanie większym niż abstrakcyjnie pojęta suma osobowości biorących udział w jego powstaniu. Autorstwo filmu powstaje na drodze interpersonalnej wymiany. Praktyka twórcza kinematografii i sztuki filmowej od ponad stu dwudziestu lat dowodzi, iż w jej przypadku mamy to czynienia z dziedziną kreacji zbiorowej, której specyfika polega na zorganizowaniu i uruchomieniu synergii procesu twórczego.

Model jednoosobowy i model addytywny autorstwa eliminują z pola widzenia konflikt rywalizujących z sobą osobowości artystycznych i podmiotów twórczych. W modelu interakcyjnym, przeciwnie, dochodzi do głosu polifoniczny dialog i synergia, będąca istotą kooperacji poszczególnych współtwórców filmu. Regulacje prawne dotyczące kwestii autorstwa utworu audiowizualnego powinny ten moment brać pod uwagę, mimo iż wywołuje on i będzie wywoływał ciągłe kontrowersje, komplikując konkretną odpowiedź na pytanie o indywidualny udział twórczy.

Specyfiką dzieł będących wynikiem kreacji zbiorowej jest sui generis szara strefa autorstwa wynikająca $\mathrm{z}$ międzyosobowej synergii poszczególnych aktów twórczych. Często niesposób tutaj wydzielić i precyzyjnie określić indywidualnego wkładu twórcy. „W naszej etyce zawodowej filmowców ważne jest to, co się filmowi daje, a nie to, czego się od niego po latach żąda" - powiedział słynny operator Jerzy Wójcik, komentując spór o autorstwo Kanału Andrzeja Wajdy rozpętany po trzydziestu latach od premiery przez Kazimierza Kutza[2]. 
W indywidualnych przypadkach różni twórcy mogą wnieść różny wkład autorski w dane dzieło. Raz większa rola przypada autorowi zdjęć (vide twórczość dokumentalna), innym razem reżyserowi i aktorom, kiedy indziej reżyserowi efektów wizualnych, montażyście, scenografowi lub twórcy charakteryzacji. Mając na uwadze złożoność przebiegu procesu twórczego, trzeba wyraźnie rozgraniczyć pojęcie autorstwa (we właściwym zakresie jego znaczenia) i pojęcie twórczości. Należy pamiętać, iż twórców utworu filmowego i audiowizualnego bywa zazwyczaj w praktyce o wiele więcej, niż jego autorów. Tylko niektórym z nich przysługuje status „autora”, co z kolei zostało usankcjonowane mocą regulacji aktów prawnych obowiązujących w danym miejscu i czasie.

\section{Autorstwo a język}

Postawmy w tym momencie kluczowe dla zagadnienia autorstwa interesującej nas kategorii artefaktów pytanie: w jakiej sferze dokonuje się akt twórczy (ergo autorstwo) utworu filmowego i audiowizualnego? Co jest w nim tworzywem, czyli sferą materialną? A co sferą symboliczną? I co wiąże obie te sfery w organiczną całość? Aby odpowiedzieć na to elementarne pytanie, posłużymy się analogią z dziełami sztuki słowa. Wiadomo, iż akt twórczy w literaturze dokonuje się w sferze języka naturalnego. To właśnie on, język polski, angielski czy włoski, jest w każdym bez wyjątku utworze literackim ową konieczną i niezbywalną substancją/materiałem/tworzywem, w której rzeźbią swoje dzieła: poeta, prozaik, dramaturg i autor tekstu piosenki.

$\mathrm{Z}$ analogiczną sytuacją mamy do czynienia w przypadku twórczości filmowej i audiowizualnej, z tą różnicą, że tworzywem, jakim posługują się i w jakim operują twórcy filmowi, jest każdorazowo język ruchomych obrazów, umownie zwany także językiem filmu lub językiem kinematograficznym [3]. Technologia czyni wprawdzie pewną różnicę operacyjną, oferując twórcom odmienne możliwości i środki wyrazu, ale generalnie nie kreuje całkiem nowego języka.

Powtórzmy: to właśnie język ruchomych obrazów jako system semiotyczny stanowi substancję, tworzywo i residuum wszelkich aktów twórczych, z jakimi mamy do czynienia w utworze audiowizualnym. W języku ruchomych obrazów „rzeźbią” i kreują swoje wizje poszczególni współtwórcy filmu. Dotyczy to także scenarzysty, który - choć posługuje się w swojej pracy słowem - projektuje nie dzieło literackie, lecz utwór kinematograficzny. W rozważaniach naszych pojawiło się wcześniej twierdzenie, iż autorstwo znaczy. Pora wyjaśnić jego głębszy sens, odwołując się przy tym do języka sztuki filmowej.

Ilekroć pytamy o kryteria oryginalności utworu audiowizualnego, najważniejszym $z$ nich okazuje się odkrywczy sposób, w jaki autor posłużył się językiem filmu. Prawo własności intelektualnej w istocie swej dotyczy właśnie tego aspektu. Autorstwo dzieła filmowego funkcjonuje w ścisłym powiązaniu z jego językową oryginalnością. Im oryginalniejsze dzieło, tym mocniej i bardziej wyraziście daje o sobie znać jego autor.

Oryginalność utworu audiowizualnego, o której mowa, nie istnieje poza językiem ruchomych obrazów i językiem sztuki filmowej będącym jego specyficzną pochodną. To właśnie kształt językowy dzieła sprawia, iż zauważamy niezwykłość jego wyrazu. Oryginalność danego utworu należy dostrzegać i odpowiednio doceniać, ale nie wolno jej absolutyzować, żadne dzieło sztuki nie jest bowiem oryginalne całkowicie: na sto procent. Pierwiastek inwencji (innowacji), jaki wnosi w różnych zakresach twórczości i na wielu poziomach przekazu, łączy się bowiem i konweniuje z elementami powtórzenia (redundantnymi konstrukcjami retorycznymi), które same w sobie są wprawdzie konwencjonalne, zapewniają jednak dziełu niezbędną czytelność.

Autorstwo jako funkcja utworu audiowizualnego

Z dotychczasowych rozważań wynika jednoznacznie, że utwór audiowizualny (resp. dzieło filmowe) nie jest sumą wkładów (tzw.

[3] M. Hendrykowski, Semiotyka ruchomych obrazów, Wydawnictwo Naukowe UAM, Poznań 2014. 


\section{VARIA}

utworów wkładowych). Utwór ten jako dzieło autorskie stanowi całość wyższego rzędu. I tak właśnie - to jest całościowo - należy rozpatrywać jego autorski charakter.

Fakt, iż mówimy o autorstwie w aspekcie danego utworu jako całości, nie stanowi bynajmniej argumentu mogącego przesądzić o tym, iż autorski udział poszczególnych współtwórców filmu traci swoją autonomię i uzasadnienie na rzecz ogólnie rozumianego autorstwa owej całości. Inny słowy, integralna jedność struktury utworu nie pozbawia poszczególnych twórców ich autorskich praw nie tylko do własnego wkładu, ale i do autorstwa całości dzieła. Wprost przeciwnie, autorstwo rozumiane jako funkcja staje się w pełni czytelne właśnie w relacji i w odniesieniu do owej całości.

Za słuszny i w pełni zasadny uważam wyrażony przez Jana Błeszyńskiego pogląd, iż „utwór audiowizualny powinien być oceniany zarówno z perspektywy jego twórcy (współtwórców), jak i z perspektywy twórców utworów wkładowych" [4]. Współpraca i autorski współudział członków zespołu mogą układać się i przebiegać w najróżniejszy sposób. W praktyce twórczej dzieło filmowe i utwór audiowizualny jako rezultat kreacji zbiorowej każdorazowo uzyskują swój kształt i artystyczny wyraz dzięki synergii, jaka towarzyszyła wysiłkom zespołu twórczego, który dzieło owo powołał do istnienia.

Technologie wytwarzania, zapisu, transmisji, dystrybucji i eksploatacji ruchomych obrazów nieustannie się zmieniają. Każda $\mathrm{z}$ nich oferuje twórcom nowe możliwości artystycznej i spo-

[4] J. Błeszyński, Prawo własności intelektualnej. Glosa do uchwały składu siedmiu sędziów Sądu Najwyższego - Izba Cywilna $z$ dnia 28 listopada 2008 r. III CZP 57/2008, „Przegląd Ustawodawstwa Gospodarczego" 2009, nr 5, s. 14. łecznej ekspresji. Należy pamiętać, iż ochrona prawa własności intelektualnej dotyczy nie wąsko pojętej substancji dzieła, która wkrótce może zostać zastąpiona przez inną, lecz jego struktury symbolicznej. Ta zaś posiada charakter par excellence językowy.

Wbrew obiegowemu przeświadczeniu właściwym tworzywem filmu nie jest taśma światłoczuła, podobnie jak tworzywem utworu audiowizualnego nowej generacji nie jest strumień elektronów. Tworzywem utworu filmowego i audiowizualnego jest za każdym razem język ruchomych obrazów, którego niezwykłe użycie czyni dany utwór kinematograficzny dziełem sztuki ruchomych obrazów. I właśnie dzieło filmowe - jako struktura semiotyczna będąca tekstem kultury - podlega autorskiej ochronie, ilekroć mówimy o własności intelektualnej, którą ono stanowi.

Scenarzysta, adaptator, reżyser, twórca zdjęć, autor utworu muzycznego i słowno-muzycznego - wszyscy oni wypowiadają się w języku ruchomych obrazów, tworząc w pojedynkę i zespołowo oryginalne dzieło sztuki i tekst kultury. O jego wartości decyduje inwencja językowa. W tej właśnie sferze realizuje się ich oryginalna twórczość, a wraz z nią autorstwo. Bez aspektu językowego i wkładu wniesionego przez indywidualnego twórcę $\mathrm{w}$ strukturę semiotyczną utworu nie ma właściwie rozumianego pojęcia autora. Status autora i przynależne mu prawa, w ścisłym powiązaniu $\mathrm{z}$ dziełem audiowizualnym i językiem ruchomych obrazów - okazują się najważniejsze i warte ochrony. Prawo własności intelektualnej powinno skutecznie chronić słabszych, czyli rzeczywistych autorów utworu filmowego i audiowizualnego. Piszemy dzisiaj nowy rozdział dziejów autorstwa filmowego w Polsce. Chodzi o to, by napisać go jak najlepiej. 